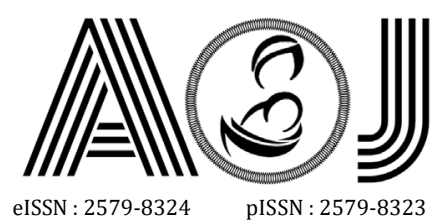

eISSN : 2579-8324
pISSN : 2579-8323

\title{
RESEARCH
}

\section{Differences of Magnesium Level Between Normal Pregnancy and Preeclamsia}

\section{Rengga Pradipta ${ }^{1}$, Roza Sriyanti ${ }^{2}$, Hafni Bachtiar ${ }^{3}$}

Affiliation author : 1. Obstetrics and Gynecology, Faculty of Medicine, Andalas University, Harapan Bunda Hospital Bandung; 2. Sub Division of Maternal Fetal Medicine, Obstetrics and Gynecology Department, Faculty of Medicine, Andalas University, Dr. M. Djamil Central General Hospital Padang; 3. Public Health Department, Faculty of Medicine, Andalas University Padang

Correspondence to: Rengga Pradipta, email: reggasuhardijanto@gmail.com, Hp: 08122025326

\section{Abstract}

Background: Preeclampsia is a multi-organ disorder that occurs in pregnant women with high blood pressure which is still difficult to predict. Until now, many theories have put forward the causes of preeclampsia, one of which is much debated is the lack of nutrition in pregnant women which can lead to preeclampsia. Several studies suggest that there is a relationship with the lack of micronutrient intake, especially magnesium, which causes preeclampsia, especially in developing countries. Magnesium deficiency is one possible factor causing severe preeclampsia. Magnesium plays a role in normal neuromuscular function, regulation of calcium, potassium and transport of sodium in the membrane as a regulation of the activation of ATP. Magnesium also plays a role in blood pressure regulation. Magnesium deficiency can lead to endothelial malfunction, hypertension and failure of the cardiovascular system. The role of magnesium is in enzyme reactions that bind to anaerobic glucose metabolism, the krebs cycle, fatty acid oxidation and reactions between coenzyme and fatty acids. Magnesium deficiency will result in changes to the nerves, muscles and blood vessels.

Methods: Analytical observational study with cross sectional design in 17 women with preeclampsia and 17 normal pregnant women who met the inclusion and exclusion criteria. Research subjects were collected at Dr M Djamil Padang General Hospital, November 2019 to January 2020. Magnesium levels were checked by enzymatic methods. The difference in the mean magnesium preeclampsia and normal pregnancy was analyzed using independent t test.

Results: Mean magnesium in preeclampsia was lower than normal pregnancy $(1.61 \pm 0.59 \mathrm{a \mu g} / \mathrm{ml} \mathrm{vs}$ $2.20 \pm 0.18, p=0.001)$.

Conclusion: Mean magnesium level in preeclampsia was significantly lower than normal pregnancy.. Keywords: Average levels of magnesium, magnesium, preeclampsia, normal pregnancy

\section{INTRODUCTION}

Preeclampsia is a multi organ which occurs in pregnant women with high blood pressure, which is still difficult to predict in pregnant woman. It is associated with significant maternal morbidity and mortality worldwide. $16 \%$ cases reported by The World Health Organization (WHO) on maternal mortality due to preeclampsia in developing countries. In 2014 Indonesia's health profile reported that almost $30 \%$ of maternal deaths in Indonesia were caused by hypertension in pregnancy. ${ }^{1}$ Based on Indonesian data, the incidence of 


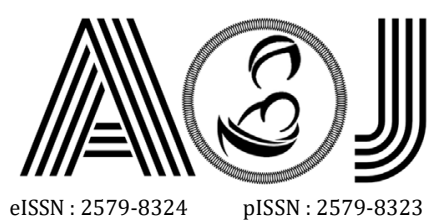

eISSN : 2579-8324
pISSN : 2579-8323

hypertension in pregnancy, especially preeclampsia is now at $5-15 \%$ cases, and it is one of the highest cause of maternal mortality in Indonesia besides infection and postpartum bleeding. ${ }^{2}$

On 2014, Padang Health Department reported that the incident of preeclampsia is 31.25\%. In Dr. M. Djamil Padang Center Hospital there was an increase in the incidence of preeclampsia from all patient that made deliveries, in 2012 there were $11.47 \%$ cases, in 2013 as many as $12.02 \%$ cases, in 2014 there was an increase again by $20.14 \%$, in 2015 as many as $32.5 \%$ cases, in 2016 increased by $33 \%$ and increase by $34.9 \%$ in $2017 .^{3}$

Preeclampsia is a serious condition that appears after 20 weeks of gestation with the main contributing factor there is an increase in maternal blood pressure. Preeclampsia is defined as a blood pressure of at least 140/90 mm measured on two occasions each 6 hours apart, accompanied by proteinuria of at least $300 \mathrm{mg}$ per $24 \mathrm{~h}$, or at least $1+$ on dipstick testing. It is clinically defined by hypertension and proteinuria, with or without pathological edema. ${ }^{4}$

There is also severe feature of preeclampsia that defined as a blood pressure of at least $160 / 110 \mathrm{mmHg}$ or higher on two occasions at least 4 hours apart with any of these findings (1) platelet count less than 100.000 /microliter (2) impaired liver function as indicated by abnormally elevated liver enzymes (twice normal concentration) (3) progressive renal insufficiency (4) pulmonary edema anda (5) new onset cerebral or visual disturbance. ${ }^{4}$

Until now, many theories that talk the causes of preeclampsia, there are several factors that are believed to cause preeclampsia, such as placental implantation accompanied by abnormal trophoblastic invasion of uterine blood vessels, maladaptive immunological tolerance between maternal, paternal, and fetal tissues, maternal maladaptation to cardiovascular or inflammatory changes that occur in pregnancy, and genetic factors, including inherited predisposing genes, as well as epigenetic influences. one of which is much debated is the lack of nutrition in pregnant women which can lead to severe preeclampsia that have relationship with endothelial disfunction. Several studies suggest that there is a relationship with the lack of micronutrient intake, especially magnesium, which causes preeclampsia, especially in developing countries. ${ }^{4,5}$

Magnesium deficiency is one of the causes of preeclampsia. Magnesium plays a role in normal neuromuscular function, regulation of calcium, potassium and transport of sodium in the membrane as a regulation of the activation of ATP. Magnesium also plays a role in blood pressure regulation. Magnesium deficiency can lead to endothelial malfunction, hypertension and failure of the cardiovascular system. ${ }^{6}$

Tavana et al in 2013 compared magnesium levels in pregnant women with preeclampsia with pregnant women with normal blood pressure, the results were lower magnesium levels in women with preeclampsia with a result of $1.81 \mathrm{mg} / \mathrm{dl}$ compared to magnesium levels in 


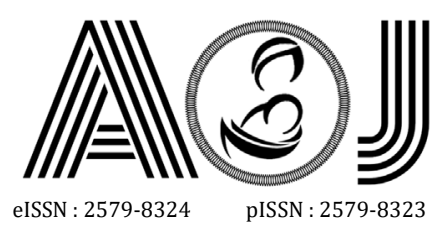

eISSN : 2579-8324
pISSN : 2579-8323

women with normal blood pressure. with a yield of $2.3 \mathrm{mg} / \mathrm{dl}$. The same thing was found in a study by Ankur in 2015 where Ankur found that the occurrence of hypomagnesemia in preeclampsia compared to normal pregnancy. ${ }^{7,8}$

There is still many controversies and study that talking about correlation about magnesium levels and incidence of preeclampsia and in Indonesia that not much study about correlation and differences of magnesium level in preeclampsia and normal pregnancy. The purpose of this study is to evaluate the differences of magnesium level in preeclampsia and normal pregnancy.

\section{METHOD}

The study was conducted at Dr M. Djamil Hospital Padang with analytical observational study with cross sectional design in 17 women with preeclampsia that is defined as hypertension with minimum criteria for systolic blood pressure $\geq 140 \mathrm{mmHg}$ and/or diastolic blood pressure $\geq 90 \mathrm{mmHg}$ after 20 weeks' gestation, and one or more proteinuria $\geq 300 \mathrm{mg} / 24$ hours or urine / creatinine protein ratio $\geq 30 \mathrm{mg} / \mathrm{dl}(1+$ urine dipstick), renal insufficiency, hematological abnormalities, liver disorders, cerebral disorders, pulmonary edema and 17 normal pregnant women (single pregnancy women, gestational age $>20$ weeks, there were no severe medical abnormalities, no chorioamnionitis and no pregnancy with major congenital abnormalities) who met the inclusion and exclusion criteria. Research subjects were collected at Dr M Djamil Padang General Hospital, November 2019 to January 2020. Magnesium levels were checked by enzymatic methods. The difference in the mean magnesium preeclampsia and normal pregnancy was analyzed using independent $t$ test. Every pregnant woman with gestational age $>20$ weeks with normal pregnancy and preeclampsia based on a diagnosis made by an obstetrician and fulfilling the inclusion criteria is given an explanation of the research to be carried out. Those who agree are asked to sign an agreement form and will be interviewed to obtain characteristic data including name, age, identity number, address, contact number, history of pregnancy, the first day of the last day or ultrasound examination to assess gestational age. Next do blood draw. After the sample is obtained, then the magnesium level is measured according to the procedure kit used.

\section{RESULTS}

The study was conducted to determine the difference in mean magnesium levels in normal pregnancy and preeclampsia based on a cross-sectional comparative study approach. The research subjects consisted of 34 respondents in two groups, namely normal pregnancy and preeclampsia. The characteristics of the respondents in this study consisted of age, gestational age, parity, and history of abortion can be seen in table 1 below.

Table 1 Respondent Characteristics 


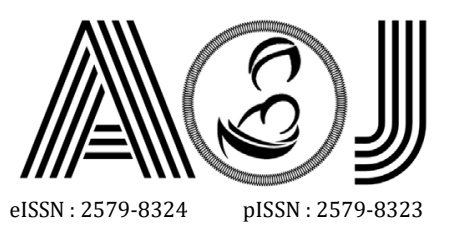

ANDALAS OBSTETRICS AND GYNECOLOGY JOURNAL

Address for Correspondence:

Editorial Room Andalas Obstetrics and Gynecology Journal, $3^{\text {rd }}$ floor of KSM of Obstetrics and Gynecology, RSUP DR. M. Djamil Padang, Jl. Perintis Kemerdekaan Padang, Sumatera Barat 25127

Website:

http://jurnalobgin.fk.unand.ac.id/index.php/JOE

\begin{tabular}{lccc}
\hline \multirow{2}{*}{ Variabel } & \multicolumn{2}{c}{ Groups } & \multirow{2}{*}{ Normal } \\
\cline { 2 - 3 } & mean \pm SD & $\begin{array}{c}\text { Preeclampsia } \\
\text { mean } \pm \text { SD }\end{array}$ & \\
\hline Age (years) & $28,35 \pm 4,69$ & $32,12 \pm 4,99$ & $0,030^{*}$ \\
Gestasional age (week), & $38,85 \pm 0,79$ & $32,50 \pm 3,14$ & $<0,001^{*}$ \\
$\begin{array}{l}\text { Parity } \\
\text { History of abortion, } \mathrm{f}(\%)\end{array}$ & $5,83 \pm 0,80$ & $4,72-7,66$ & 0,084 \\
$\quad$ & & & \\
$\quad$ Yes & $3(17,6)$ & $1(5,9)$ & 0,601 \\
$\quad$ No & $14(82,4)$ & $16(94,1)$ & \\
\hline
\end{tabular}

Table 1 shows that there are differences in age and gestational age in normal pregnancy and preeclampsia $(p<0.05)$. Where the age in normal pregnancy is 28 years and preeclampsia is at 32 years. At gestational age, the mean gestational age was 38 weeks at normal pregnancy and 32 weeks at preeclampsia. However, there was no difference in parity and history of abortion with normal pregnancy and preeclampsia $(p>0.05)$. In this study, the normal delivery group found a mean of 5 deliveries compared to the preeclampsia group with an average of 4 deliveries.

Table 2 Difference in Average Magnesium Levels in Normal Pregnancy and Preeclampsia

\begin{tabular}{lcccc}
\hline \multicolumn{1}{c}{ Magnesium $(\mu \mathrm{g} / \mathrm{ml})$} & $\mathbf{n}$ & Mean \pm SD & Min-Max & p-value \\
\hline Normal Pregnancy & 17 & $2,20 \pm 0,18$ & $2,00-2,57$ & $0,001^{*}$ \\
Severe Preeclampsia & 17 & $1,61 \pm 0,59$ & $0,44-2,08$ & \\
\hline
\end{tabular}

Table 2 shows that the average magnesium level in normal pregnancy is $2.20 \pm 0.18$ $\mu \mathrm{g} / \mathrm{ml}$ which is higher than preeclampsia, namely $1.61 \pm 0.59 \mu \mathrm{g} / \mathrm{ml}$, based on the results of statistical tests using the independent sample T test, the $p$ value is obtained. $=0.001(p<0.05)$, it can be concluded that there are differences in the mean magnesium levels in normal pregnancy and preeclampsia.

The results showed that the average magnesium level in normal pregnancy was $2.20 \pm$ $0.18 \mu \mathrm{g} / \mathrm{ml}$, higher than preeclampsia, namely $1.61 \pm 0.59 \mu \mathrm{g} / \mathrm{ml}$. The results of this study are supported by research by Syaikh (2012) which states that the magnesium level in the group with normal pregnancy is $1.5 \mu \mathrm{g} / \mathrm{ml}$ while in preeclampsia it is $1.16 \mu \mathrm{g} / \mathrm{ml}$. Another study conducted by Tavana (2013) found that magnesium levels were lower in the preeclampsia group compared to normal pregnancies $(1.81 \pm 0.25 \mathrm{mg} / \mathrm{dl}$ vs. $2.3 \pm 0.44 \mathrm{mg} /$ dl). Kanagal (2014) stated that serum magnesium levels were lower in the preeclampsia group compared to normotentives $(1.43 \pm 0.55 \mathrm{mg} / \mathrm{dl}$ vs $1.57 \pm 0.72 \mathrm{mg} / \mathrm{dl}) .^{7,9,10}$

The results found that there were differences in the mean levels of magnesium in normal pregnancy and preeclampsia. The results of this study were supported by research by Shaykh (2012) which stated that preeclampsia in pregnancy was observed to be significantly higher in the normal pregnancy group compared to the preeclampsia group $(p=0.003, p$ 


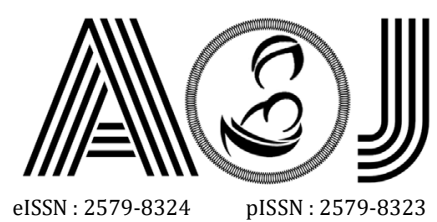

eISSN : 2579-8324
pISSN : 2579-8323

$<0.05)$. Another study by Tavana (2013) found that there were differences in the mean magnesium levels in the preeclampsia group compared to normal pregnancies. Research conducted by Bullarbo (2018) regarding the effect of magnesium supplementation in healthy pregnant women in preventing an increase in blood pressure during pregnancy showed that there was a statistically significant difference between healthy pregnant women who received magnesium supplementation and the group of pregnant women who received a placebo in preventing the occurrence. Increase in blood during pregnancy. Arun's research (2017) found that serum magnesium levels in the group with preeclampsia (1.83 $\pm 0.21 \mathrm{mg} /$ $\mathrm{dl})$ were lower than the group with normal pregnancy $(2.03 \pm 0.16 \mathrm{mg} / \mathrm{dl})$. This study proves a decrease in magnesium levels with the occurrence of preeclampsia in women. ${ }^{7,9,11,12}$

In an effort to increase magnesium levels as an effort to prevent preeclampsia, it can be done through magnesium supplementation and also increasing the intake of foods that contain lots of magnesium such as whole grains, green vegetables, soybeans, nuts, dried fruits, animal protein and food. sea and increase the understanding of mothers about the importance of magnesium in pregnancy. ${ }^{6}$

Based on the researcher's analysis, there are differences in magnesium levels in normal pregnancy and severe preeclampsia because magnesium levels have an important role in controlling blood pressure. In addition, magnesium also plays a role in heart muscle contraction, if the concentration of magnesium in the blood decreases, the heart muscle cannot work optimally, which affects blood pressure.

\section{CONCLUSION}

Based on the results of the research and discussion, it can be concluded that the average magnesium level in normal pregnancy is $2.20 \pm 0.18 \mu \mathrm{g} / \mathrm{ml}$. The mean magnesium level in preeclampsia is $1.61 \pm 0.59 \mu \mathrm{g} / \mathrm{ml}$, there is a difference in the mean magnesium level in normal pregnancy and preeclampsia where the average magnesium level in normal pregnancy has a higher value than preeclampsia.

\section{REFERENCES}

1. Magee L, Von D. State-of-the-Art Diagnosis and Treatment of Hypertension in Pregnancy. Mayo clinic proceedings. 2018;93:1664-1677.

2. Fitrayeni. Faktor risiko kejadian preeklampsia pada ibu hamil di RSUP Dr M Djamil Padang Tahun 2014. JKMA.38-44.

3. Padang DrmRDMD. Data rekam medis RSUP Dr. M Djamil Padang. 2011-2017.

4. Cunningham FG, et al. 2014. Hypetensive disorder in pregnancy. Dalam William Obstetric 23 ed. New York: McGraw-Hill Companies Inc 


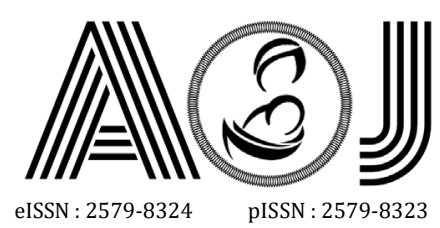

5. Ukah DV, Payne B. Prediction of adverse maternal outcomes from pre-eclampsia and other hypertensive disorders of pregnancy: A systematic review. International Society for Study of Hypertension in Pregnancy. 2018;11:115-123.

6. Gröber U, Schmidt J, Kisters K. Magnesium in Prevention and Therapy. Nutrients. 2015;7 (9):8199-8226.

7. Tavana Z, Hosseinmirzaei S. Comparison of Maternal Serum Magnesium Level in Preeclampsia and Normal Pregnant Women. Iran Red Cres Med J. 2013;15 (12):10394.

8. Ankur P, R.K V. Serum Magnesium Status In Preeclamsia. . International Journal Of Medical science and Education 2015.

9. Syaikh K, Das C, Baloch G, Abbas T, Fazlani K, Jaffrey M. Magnesium associated complications in pregnant women. World Appl Sci J. 2012;17 (9):1074-1078.

10. Kanagal D, rao ARK, Devi U, Shetty H, Kumari S, Shetty P. Level of Serum Calcium and Magnesium in Pre-eclamptic and Normal Pregnancy A Study from Coastal India. J Clin Diagn Res. 2014;8 (7):OC01-04.

11. Bullarbo $\mathrm{M}, \mathrm{H} M, A K B, N \mathrm{O}, \mathrm{TF} \mathrm{N}$. Clinical study magnesium supplementation and blood pressure in pregnancy: a double blind randomized multicenter study. Journal of Pregnancy. 2018:1-10.

12. Arun D, B A, M R, K C. A comparative study of serum uric acid, glucose, calcium and magnesium in eclampsia and normal pregnancy. . Journal of Pathology of Nepal. 2017;7:1155-1161. 